\title{
Optimizing oral immunotherapy to cow milk protein: a decision analysis
}

\author{
Elinor Simons ${ }^{*}$, Myla Moretti ${ }^{2}$ \\ From Canadian Society of Allergy and Clinical Immunology Annual Scientific Meeting 2010 \\ Victoria, Canada. 3-6 November 2010
}

\section{Background}

Oral immunotherapy (OIT) to cow milk protein (CMP) allows some children with cow milk allergy (CMA) to outgrow their allergy sooner, but increases their initial risk of anaphylaxis.

\section{Methods}

We used Markov transition models to compare the expected lifetime gain in quality-adjusted life years (QALYs) of OIT to CMP versus strict avoidance of CMP. Models were run for base cases of 6- to 16-yearold children with CMA requiring strict CMP avoidance. Rates of transition to the partial or full desensitization and complete tolerance states, utilities for each state, and disutilities and durations of reactions were determined from the literature. Participants progressed through the OIT states in order but could regress to an earlier state or repeat OIT.

\section{Results}

For an 8-year-old child, OIT resulted in a 0.9 QALYs gain compared with strict avoidance; this benefit increased to 1.9 QALYs for a 16-year-old. Sensitivity analysis showed that OIT became the preferred strategy within 6 years of starting OIT. The models were sensitive to the state utilities, but not to the transition probabilities between states. Probabilities of reactions had to be over 10 times the literature-based estimates for OIT to no longer be the preferred strategy. Limitations of these models included the paucity of utility measures for children with CMA and the possible under-reporting of CMA-related reactions or death.

\footnotetext{
* Correspondence: elinor.simons@sickkids.ca

${ }^{1}$ Child Health Evaluative Sciences, The Hospital for Sick Children, Toronto, ON, Canada M5G 1 X8

Full list of author information is available at the end of the article
}

\section{Conclusions}

For children with CMA, OIT offers improved QALYs and the benefits outweigh the risks within a few years. Determination of utilities for younger children with CMA will help to further address this question.

\section{Author details}

${ }^{1}$ Child Health Evaluative Sciences, The Hospital for Sick Children, Toronto, ON, Canada M5G 1X8. ${ }^{2}$ Department of Pharmacology, The Hospital for Sick Children, Toronto, ON, Canada M5G 1 X8.

Published: 4 November 2010

doi:10.1186/1710-1492-6-S2-P7

Cite this article as: Simons and Moretti: Optimizing oral immunotherapy to cow milk protein: a decision analysis. Allergy, Asthma \& Clinical Immunology 2010 6(Suppl 2):P7.
Submit your next manuscript to BioMed Central and take full advantage of:

- Convenient online submission

- Thorough peer review

- No space constraints or color figure charges

- Immediate publication on acceptance

- Inclusion in PubMed, CAS, Scopus and Google Scholar

- Research which is freely available for redistribution 